\title{
Rendzina (rędzina) - Soil of the Year 2018 in Poland. Introduction to origin, classification and land use of rendzinas
}

\begin{abstract}
Following the other pedological societies, the Soil Science Society of Poland has launched a programme „Soil of the Year", and Rędzina (Rendzina) was selected as the soil inaugurating the programme in 2018. Polish term ,rędzina” was internationally popularized by Stanisław Miklaszewski in the second/third decade of $20^{\text {th }}$ century and is present in the most soil classification systems as „Rendzina”, „Rendoll”, or „Rendzic” until now. In the Polish tradition, the rendzinas are soils developed from massive rocks rich in calcite, dolomite or gypsum, quite often with admixtures of glacial/periglacial materials, at all development stages. Contemporary classifications of soils in Poland distinguish four main groups (as the types or sub-types): raw rendzina - Calcaric Lithic / Hyperskeletic Leptosols (a minimal thickness of regolith and an initial development of genetic horizons), proper rendzina Calcaric Leptosols (medium thick profile, but diagnostic horizons are absent), brown rendzina - Calcaric Skeletic Cambisols (have a diagnostic cambic horizon), and chernozemic/humic rendzina - Rendzic Skeletic Phaeozems (have a diagnostic mollic horizon). Rendzina soils are featured by high content of calcium/magnesium, neutral and alkaline reaction, and high base saturation throughout the soil profile, but the individual soil subtypes differ significantly in their usability for agriculture and forestry, depending on the thickness of the soil profile (i.e. a depth to the hard rock or extremely skeletal subsoil), stoniness, texture, and humus content.
\end{abstract}

Keywords: rendzina, Rendoll, Rendzic, soil origin, soil classification, soil functions

\section{INTRODUCTION}

Although soils play various key functions in the ecosystems and human economy, the knowledge about soils and the understanding of the need to protect them is insufficient in the public space. Therefore, various initiatives should be constantly undertaken to increase the awareness of the importance of soils for the global/national food security, their properties and diversity as natural resources. One of such initiatives is the program „Soil of the Year” initiated by the German Soil Science Society in 2005 (Altermann et al. 2005), currently implemented not only in Germany and neighbouring countries, but also in other countries of Europe and world (Kölli and Tamm 2015). Also, the idea of proclaiming a similar program has appeared in the Soil Science Society of Poland (SSSP) during the Jubilee of the $80^{\text {th }}$ anniversary of SSSP. The coordination of the program was entrusted to the Commission of Soil Genesis, Classification and Cartography (CSGCC) of SSSP. The program "Soil of the Year" has a broad formula and emphasizes both the scientific aspects and the primary educational and popularizing goals. The rapid changes in the human-dominated environment generate new challenges for science. These challenges in the field of soil sciences are related, for example, to changes in agricultural and forestry technologies, urbanization and industrialization, large-scale human interference in the environmental quality, and recently also to the global climate changes. Soil science,despite its almost 150 -year-long history, constantly faces new research problems. The program "Soil of the Year" is therefore aimed not only at popularizing the knowledge already gathered, but also at concentrating the attention of researchers on the challenges and future research needs. Among many considered „candidate soils", rędzina (rendzina) was selected as the first "Soil of the Year 2018" at a special meeting of CSGCC on the $7^{\text {th }}$ December 2017, organized at the Warsaw University of Technology (Politechnika Warszawska). The place has not been selected incidentally - it was the host university of professor Sławomir Miklaszewski, the most famous among the researchers and popularisers of rendzina soils (Skłodowski 2014, Kabała 2017). One of the initiatives under the Soil of the Year 2018 is a preparation of special issue of Soil Science Annual with a set of papers presenting the current state of knowledge about the spatial occurrence and variability of rendzinas in Poland. The present text is a kind of introduction to this special collection of papers. 


\section{NAME, ORIGIN AND GENERAL CLASSIFICATION OF RENDZINA SOILS}

The original term „redzina” is derived from onomatopoeic word „rzędzić", i.e. from the grit of shards of hard limestone to the blade of the plow. According to Miklaszewski (1930), the name "rędzina" was used on the left bank of the Vistula river (Kielce region), whereas on its right bank (Lublin region) the same soils were referred to as "borowina". Due to the fact that the "borowina" was also used to determine many other soil types, including peat soils, Miklaszewski has decided to use "rędzina" as a more specific and unambiguous term.

Many renowned researches have investigated rendzina soils in the central and south-eastern Poland before the World War I and further, until the 1939 (Miklaszewski 1930, Mieczyński 1932, Musierowicz and Wondrausch 1936). The idea to introduce soil type developed on limestones and the term ,rendzina” have been popularized internationally by Miklaszewski, who has broad contacts and impacts as a member of the Committee for Soil Nomenclature and Classification at the International Soil Science Society (ISSS) and also as a member of the Committee for Soil Map of Europe (Miklaszewski 1922, Stremme 1932). In the original Miklaszewski's depiction, rendzinas are loamy textured soils developed of calcareous rocks (limestones, dolomites, marls and other similar rocks), having a dark grey or black topsoil horizon, rich in active ("sweet") humus, ensuring high agricultural productivity. Already this approach, that combines limestone bedrock and thick, black, humus-rich topsoil, has become a "standard" of rendzina in an international soil science and is present to this day in the definitions of Rendzina, Rendoll or Rendzic in many local and international classifications (Ad-Hoc-Arbeitsgruppe 2005, Badía et al. 2014, Soil Survey Staff 2014, IUSS Working Group WRB 2015, Radmanović et al. 2015, Harbar and Poznyak 2016). Soon later, Miklaszewski has expanded the concept of rendzina soils, introducing the division into black, white and yellow rendzinas, as well as red lateritic rendzinas, assigning them different agricultural value associated with the kind and age of the parent rock. However, Miklaszewski did not use a distinction based on the advancement of the soil-forming process, in particular, did not use the term "brown rendzina" due to his objection to the concept of "brown earths" (Miklaszewski 1930). In Miklaszewski's opinion, rendzinas are the soils often "rejuvenated" by erosion, but are resistant to "podzolization" (i.e. various eluvial processes) due to high content of calcium carbonate. This component is also a factor stimulating organic matter accumulation in topsoil. Apart from the in-situ weathering soils, Miklaszewski has also characterized a range of transitional forms, containing admixtures of glacial and aeolian deposits, giving them specific names such as "przyrędzinki" (dominated by limestone stones but having addition of eolian material), "przypiaski" (dominated by eolian sand with only little admixture of limestone stones and gravels), mixed rendzinas etc. (Miklaszewski 1930). Mechanical and chemical weathering of limestone rocks produces the crucial substrate for rendzina, which, however, may undergo various geomorphological transformations, e.g. denudation (including the chemical dissolution and leaching), mass movement, surface wash (erosion), etc. A range of different rendzina soils may therefore exist in the landscape, including the "colluvial rendzina" (i.e. accumulated on glacial/glaciofluvial sediments), "mixed rendzinas" i.e. soils with an admixture of glacial materials or developed from stratified or mixed slope covers, calcareous and non-calcareous (Strzemski et al. 1973). These are also soils those affiliation to rendzinas is questionable, such as soils developed on hard dolomite stonedebris with a quarzitic sand infilling, mentioned as "przyrędzinki" and "przypiaski” by Miklaszewski (1930).

Until the late-1950s, the classification of rendzinas in Poland was based on the kind and age of parent rock, dividing them into gypsum rendzinas and carbonate rendzinas, and then into Tertiary, Cretaceous, Jurassic, Devonian, and other rendzinas (Dobrzański i in. 1953, Musierowicz 1954, Dobrzański 1955). A crucial change was decided in the $2^{\text {nd }}$ edition of the Genetic Classification of Polish Soils (Genetyczna klasyfikacja gleb Polski 1959), in which the priority was given to the soil development level (the advancement of the soil-forming process) and thus, three rendzina types were distinguished: rendzina of the initial stage of development with undifferentiated profile, brown rendzina, and chernozemic rendzina. The kind and age of the parent rock was considered a significant, but secondary factor, in line with the depth of the soil profile and soil texture. This change resulted from a common observation, that the addition of glacial/periglacial material may be more influential on the properties of rendzina profile than the age of bedrock limestone. Also, it should be noted that not only gypsum, limestone, dolomite and marl, but also "other massive rocks rich in $\mathrm{Ca} / \mathrm{Mg}$ carbonates", e.g. sandstones and shales, were included as possible parent rocks of rendzina soils.

In the $3^{\text {rd }}$ edition of Polish Soil Classification (Systematyka gleb Polski 1974), the carbonate-rich soils were separated into two types: rendzina soils (developed from highly carbonatic limestones, dolomites 
and marls) and pararendzina soils (developed from calcareous sandstones, shales and other soils). In the rendzina type, the list of subtypes was extended to seven units: raw/initial, proper, chernozemic, brown, mountain humus, mountain tangel, and the relic red rendzinas (terra rossa type). In the subsequent editions of Polish Soil Classifications (Systematyka gleb Polski 1989, 2011) and in the Classification of Forest Soils of Poland (2000), the division into four main units was maintained (raw, proper, brown, and chernozemic/humus rendzinas), initially at the rank of soil subtypes, and from 2011 - soil types (the English translations of rendzina names are given after Świtoniak et al. (2016)). Mountain tangel rendzinas are mostly associated with proper rendzinas, whereas the red rendzinas - with brown rendzinas (Dobrzański et al. 1987, Kuźnicki et al. 1976). The introduction of 'pararendzina' as a separate unit was reflected in many research papers (e.g. Zasoński and Skiba 1988, Zasoński 1992), but this introduction caused numerous classification and cartographic troubles, because not the soil properties but the properties of parent rock have decided about the soil classification in this case (Kowalska et al. 2017, Niemyska-Łukaszuk et al. 2004). The introduction of pararendzina did not solve the problem of so-called quaternary or post-lake rendzinas, i.e. soils formed from strongly drained limnic sediments (such as carbonatic gyttja), whose position in the classification is still unclear (Uggla 1976, Lemkowska and Sowiński 2008, Lemkowska 2013).

The area occupied by rendzinas is estimated at $0.75-1 \%$ of Poland's territory, depending on the criteria for enrolment to the "mixed" rendzinas. Among the agricultural soils, rendzina comprise about 1.2-1.5\% (Mocek 2015, Smreczak et al. 2018, Strzemski et al. 1973). Rendzina soils are mapped mainly in the highlands of central-southern Poland, that is the Kraków-Częstochowa Upland, Kielce Upland, Lublin Upland and Silesian Upland, as well as in the mountains, i.e. in the Carpathian Foothills, Pieniny Mts., Tatra Mts., and in the Sudeten Mts. In the administrative terms, the largest areas covered by rendzinas are indicated in the Świętokrzyskie and Lubelskie voivodships (regions), and then in the Śląskie, Małopolskie, Opolskie, Podkarpackie and Łódzkie voivodships (Smreczak et al. 2018).

\section{CHARACTERISTIC, CLASSIFICATION AND LAND USE OF RENDZINAS}

\section{Raw rendzina (rędziny inicjalne)}

Raw (rocky) rendzina is the first stage of rendzina development, that corresponds with the Calcaric
Lithic Leptosols in WRB (IUSS Working Group WRB 2015), and includes soils at the initially or poorly advanced limestone weathering. Most often these soils have a few-centimeter thick regolith (Klasyfikacja gleb leśnych Polski 2000, Systematyka gleb Polski 1989, Miechówka and Drewnik 2018), thus their profile is typically described as O-ACca-Rca (symbols and rules used for soil profile description are after the Fieldguide for soil description (Polskie Towarzystwo Gleboznawcze 2017)); however, also soils without any mineral regolith, but having a few-centimeter thick organic layer (litter) may be included (Systematyka gleb Polski 2011), that correspond with Nudilithic Leptosols in WRB. The shallow profile of these soils may result not only from the poor advancement of the weathering processes, but also from the high intensity of erosion, which "rejuvenates" the weathering profile. It is obvious that the raw rendzinas do not have any diagnostic horizons, excluding the ochric one. ACca horizons of the raw rendzinas are characterized by high content of calcium (sometimes also magnesium) and neutral $\mathrm{pH}$. The shallow profile and high stoniness resulting from the presence of these soils on exposed rock outcrops, make these soils practically unprofitable for agriculture. Moreover, the shallow profile and susceptibility to drought, or the harsh climate conditions in the high mountain zones eliminate these soils to be used in forestry (Komornicki and Skiba 1996). Finally, the raw rendzinas are mostly covered with the natural or seminatural communities of xerothermic vegetation, on-rock communities and grassland communities, for example the Drabo-Artemisietum petrosae, Papaveri-Cerastietum latifolii, Salicetum retusae alpinetosum, Asplenio viridis-Cystopteridetum, Asplenitum rutae murariaetrichomanis and other (Klasyfikacja gleb leśnych Polski 2000, Miechówka and Drewnik 2018).

The raw rendzina group includes also the raw debris rendzinas, whose whole profile consists of coarse-grained limestone material accumulated in various slope debris, debris cones, or stony-rubble covers (Kacprzak et al. 2006). The fissures between rubble debris are filled with mineral-organic or organic material only in the near-surface part of the cover, as a few-centimeter thick layer, which may be recorded as OCca-Cca or O-ACca-Cca, and corresponds with Calcaric Hyperskeletic Leptosols (Kabała et al. 2016). Although they have the hard rock at a larger depth, the soils are shallow in the biological sense and extremely susceptible to droughts. A serious problem, especially on the active debris cones, is also the instability of the debris, that eliminates trees. Similarly to the raw rocky rendzinas, the raw debris rendzinas are also useless for agriculture and have minimal 
importance for forestry, but may host various interesting communities of natural vegetation (Silenetum prostratae, Gymnocarpietum robertiani, Papaveri-Cerastietum latifolii and others), sometimes beeing also unique environments for rare fauna species, as for mountain Apollo (Parnassisus apollo).

Debris rendzinas with thicker layer of organic or organic-mineral material, and thus ensuring better retention and availability of water and nutrients, are classified as proper rendzinas.

\section{Proper rendzinas (rędziny właściwe)}

The proper rendzinas are soils at more advanced development stage, where the thickness of the soil profile reaches several centimeters, the well-developed A horizon has 1-3\% (and more) of humus, and shallow/ weakly developed B horizon may occur, but any diagnostic horizon still is lacking, except for the ochric one. The soil profile may be therefore described as O-A(ca)-ACca-Cca-Rca and correlated with Calcaric Leptosols. The classifications have sometimes determined the maximum thickness of the profile e.g. at $50 \mathrm{~cm}$ (to hard rock or extremely skeletal regolith, as in Calcaric Skeletic Leptic Regosols), but it seems that a better distinguishable feature of this group is the lack of fully developed diagnostic horizons (except for ochric and folic). A + AC horizons usually have a thickness of 10-30 cm and the loamy texture, are strongly skeletal and have a neutral or weak acidic reaction (Klasyfikacja gleb leśnych Polski 2000, Systematyka gleb Polski 2011, Miechówka and Drewnik 2018). Despite the relatively high stoniness, the proper rendzinas located on the smooth-inclined slopes are still used by farmers, but these are relatively poor soil, usually classified as $\mathrm{IVb}$ and $\mathrm{V}$ (in the lower positions) and V-VI (in the mountainous areas) classes of the arable lands, and as IV and V classes of meadows and pastures (Strzemski et al. 1973). The proper rendzinas create an eutrophic forest habitat, in the lower mountain zones - appropriate for the deciduous or mixed forests with a predominance of beech or fir (so called "fertile Carpathian beech forests", Dentario glandulosae-Fagetum). With increasing altitude, the climate is getting harsher, which initially weakens and then gradually eliminates the beech and fir in favour of spruce. The Polish forest habitat classification refers such sites as the "mountain broadleaf mixed forest" habitat, and, at the boundary with the upper climate zone, as the "mountain coniferous mixed forest" habitat (Lasota et al. 2018).
The proper rendzinas include also the "raw humus/ tangel rendzinas" (rędziny butwinowe), which generally have a thin profile, but thicker than the raw rocky rendzinas (hard rock often below $30 \mathrm{~cm}$ from the surface), but also have a thick (typically $>20 \mathrm{~cm}$ ) organic horizon predominated by the weakly humified litter debris. Soils are described as Ol-Of-Oh-AC-Cca-Rca, and may be correlated with Calcaric Folic Leptosols. This humus type is often referred to as tangel or amphi (Miechówka and Drewnik 2018). An important source of organic debris is the throughfall of spruce needles and branches, which contributes to the strongly acid reaction of the organic layer (usual pH 3-4), despite the neutral reaction of mineral soil $(\mathrm{pH} 6-7.5)$ and the high abundance of limestone rock fragments. The "raw humus/tangel rendzinas" are typical „climatogenic” soils and their occurrence is limited to the upper mountain or subalpine zones. Also the forest communities occurring on these soils are controlled by climate, and, for example, may represent the "high-mountain spruce forests on limestones" (Polysticho-Piceetum) and "mountain pine forests" (Pinetum mughi calcicolum).

Also many of the debris rendzinas (rędziny właściwe rumoszowe) are included into the proper rendzina group. These soils, similarly to the raw debris rendzinas, are built of coarse-grained calcareous material, but the infilling with mineral-organic organic material (litter, mursh, etc.) in the fissures between rock fragments is thicker (Skiba and Komornicki 1983, Zaleski et al. 2016). The (proper) debris rendzina may be correlated with the Calcaric Folic Hyperskeletic Leptosols and their profile may be described as $\mathrm{O}-\mathrm{O} / \mathrm{Cca}-\mathrm{Cca}$ or O-ACca-Cca. These soils, despite the permeable substrate, are deep soils in the biological sense, very rich in calcium and other nutrients, and sometimes surprisingly humid due to high water retention ability of organic or organicmineral material (Zwydak 2011). They occur on the stabilized debris covers or debris cones, in such positions, where the slope morphology favours an accumulation of the plant litter (Bodziarczyk 2004). These soils do not have agricultural importance, but they create specific eutrophic habitats for the sycamore forests with hart's-tongue ferns (Phyllitido-Aceretum), found locally in the low-mountain forest zone. According to the WRB system (IUSS Working Group WRB 2015) and Polish Soil Classification (Systematyka gleb Polski 2011), the coarse-grained debris rendzinas with organic infilling thicker than $40 \mathrm{~cm}$ are classified as organic soils, so called folisols - Calcaric Mawic Histosols, that reflects the special importance of a thick layer of accumulated organic matter (even if litter) in the hyper-skeletal debris. 


\section{Brown rendzinas (rędziny brunatne)}

Brown rendzinas, as their name suggests, are featured by distinctly developed subsurface graybrown, brown or rusty-brown coloured horizon, $15-40 \mathrm{~cm}$ and more thick, developed in course of weathering and biogenic transformation, that meets the criteria for the diagnostic cambic horizon (Brożek and Zwydak 2003, Zaleski et al. 2016). Probably, this group of rendzinas is the most widespread among all rendzina types, both in agricultural space and under forests, but it is also the most diverse group in terms of their origin, morphology and physicochemical properties (Mazurek et al. 2018). The brown rendzinas developed purely from the in-situ formed regolith usually have a loamy texture and high content of calcareous rock fragments throughout the profile, subsequently increasing with depth. In the brown rendzinas developed of slope covers or having a larger admixture of glacial/periglacial materials ("mixed rendzinas"), the soil texture may vary from sandy, through loamy and silty to clayey; stoniness may change irregularly (or change abruptly) within the profile, and the non-calcareous rock fragments (i.e. granite, gneiss, cherts, sandstone, etc.) may be present among the soil skeleton. Carbonates may occur throughout the soil profile, but they may also be absent in topsoil. The reaction of brown rendzinas may be alkaline or neutral throughout the profile; however, in most soils it is slightly acid ( $\mathrm{pH}$ 5.5-6) in topsoil, sometimes also in Bw horizons. This may not be a result of pedogenic decalcitation, but due to an admixture of non-calcareous material. The mineral A horizon of forest brown rendzinas usually has a thickness of 10-20 cm (in arable soils - up to $30 \mathrm{~cm}$ ), it is rich in humus (1-3\%) of a mull type, has a stable aggregate structure (most often granular one), but does not meet all the criteria for the mollic diagnostic horizon (IUSS Working Group WRB 2015). A typical record of the brown rendzinas profile is as follows: Ap-Bwca-BC$\mathrm{Cca}(-\mathrm{Rca})$ and Ol-A-Bwca-BC-Cca(-Rca). Typically the brown rendzinas are correlated with Calcaric Skeletic Cambisols. Likewise, the record of brown gypsum rendzinas is similar (Ap-Bwcs-BC-Ccs (-Rcs)), but their position in the WRB classification is slightly different (Eutric Gypsiric Skeletic Cambisols), which reflects the lack of carbonates. However, rendzinas developed on the gypsum bedrock may also have admixture of allogenic material and may contain carbonates (Mazurek et al. 2018). In this case, their profile may be recorded as Ap-Bwca-BC-Ccacs(-Rcs) and soils may be correlated with Calcaric Gypsiric Skeletic Cambisols. Brown rendzinas, depending on the depth of the soil profile (to the hard rock or extremely stony regolith), stoniness, texture and location, are evaluated in IIIa, IVa and IVb classes of arable lands in lowland/upland locations, and from IVb to VI class in the mountains. The most important factors limiting their agricultural usefulness are the stoniness and susceptibility to seasonal drought (Smreczak et al. 2018). In spite of the calcareous substrate, many mixed brown rendzinas require liming to prevent topsoil acidification under an intense mineral fertilization (Strzemski et al. 1973). In forestry, the brown rendzinas are considered eutrophic soils, forming the well-drained habitats for broadleaf forests, in particular the upland oak-bornbeam communities (TilioCarpinetum, Galio-Carpinetum) and fertile variants of mountain beech forests (Dentario glandulosaeFagetum, Dentario enneaphyllidis-Fagetum), whereas in sunny and warm sites (on slopes with $\mathrm{S}$ or SW exposures), the patches of the orchid beech (TaxoFagetum) or thermophilic fir-beech forests (Carici albae-Fagetum) may form (Lasota et al. 2018).

The red rendzinas (rędziny czerwonoziemne) comprise a group of soils developed from red and brown relic saprolites originated due to weathering of older calcareous rocks in Tertiary period. They include both the so-called terra rossa - Calcaric Rhodic (Leptic) Cambisols and so-called terra fusca - Calcaric Chromic Cambisols which are traditionally included into brown rendzinas in Poland. The results of the weathering of carbonate rocks under the warm/ hot climate are not only the dark-cherry or yellowchestnut colours, but also the heavy loamy or clayey texture. These soils have typically a shallow humus horizon $(10-15 \mathrm{~cm})$, sometimes thickened by plowing up to $25-30 \mathrm{~cm}$, medium-rich in humus (most often $1-2 \%)$, rich in carbonates. The topsoil horizon (ochric) contains a mull humus, has the neutral or alkaline reaction, and has a strong granular or blocky subangular structure. Also the subsurface cambic horizon has a stable aggregate structure and sometimes the marks of vertilisation (including the prismatic structure, vertical cracks, and shiny aggregate surfaces). In the typical form, these soils occupy rather small patches on the outcrops of limestones and dolomites. Eroded, may be a source of clayey, cherry-coloured colluvium with vertilisation features and strong stagnic properties in the profile (author's observation from Olkusz area, yet unpublished). The crucial problem related to identification of these soils it to confirm the presence of the cambic horizon, e.g. based on the development of pedogenic soil structure. The features related to the relic rubification are in fact lithogenic features, inherited, and alone cannot be the base for classification of the modern (surface) soil (Zagórski 2003; Zagórski and Kaczorek 2002). 


\section{Chernozemic rendzinas \\ (rędziny czarnoziemne)}

A common feature of all chernozemic rendzinas is the presence of a dark-grey or black topsoil horizon (a diagnostic mollic), that is thick (usually $>30 \mathrm{~cm}$ ), rich in humus (usually $>3 \%$ ), biologically active, and structural (strong granular, coprolite, or subangular blocky structure). The whole profile has a neutral or alkaline reaction, although carbonates may be absent in the topsoil layer. The rendzinas on gypsum may have an acidic subsoil, but it is not an obligatory rule (Ciarkowska and Miechówka 2018). The thickness of the profile varies; the thickest (often $>120 \mathrm{~cm}$ ) are rendzinas developed from Cretaceous limestones and „travertines” (e.g. in the Muszkowice/Henryków area in SW Poland), whereas the shallowest (often $<50 \mathrm{~cm}$ to the hard/cracked rock) are rendzinas developed from Triassic limestones and gypsum (Smreczak et al. 2018). The texture of "pure" (weathering in situ) chernozemic rendzinas is generally loamy, whereas the "mixed" rendzinas often have silty or silt-loamy texture, but also sandy texture (loamy sand) was found. The soil profile of chernozemic rendzina may be recorded as follows: Ol-A-ACca-Cca(-Rca) or Ap-ACca-Cca(-Rca) and the soil group may be correlated with the Rendzic (Skeletic) Phaeozems (also applicable to rendzinas on gypsum as Gypsiric (Skeletic) Phaeozems).

Among the rendzinas, the chernozemic ones represent the highest agricultural value and often are evaluated as I and II class of the arable lands in Poland. Although of course, the thinner soils, developed of hard limestones and situated in unfavorable locations, can be reported even in the classes IVa and IVb (Strzemski et al. 1973). In the vast majority, the chernozemic rendzinas are under ploughing, and the few of them, which are under forests, form the eutrophic habitats of rich broadleaf forests with hornbeam-featured communities (Tilio-Carpinetum).

A group of rendzinas separately identified in the mountainous areas are the humus-rich mountain rendzinas (rędziny próchniczne górskie), correlated with Calcaric Skeletic Leptic Phaeozems or Skeletic Leptic Rendzic Phaeozems, whose topsoil layer is dark-gray or black and usually contains $>3 \%$ of humus, most often of a mull-form, but sometimes murshic-like type. The thickness of this horizon is highly variable, from $20 \mathrm{~cm}$ to $40-70 \mathrm{~cm}$ (Systematyka gleb Polski 1989, Zaleski et al. 2016, Miechówka and Drewnik 2018), which is to a certain extent correlated with the depth of the entire profile. The thinner humus-rich rendzinas occur typically at the higher altitudes and in the higher slope positions, whereas the thicker ones occur at the lower altitudes and in the lower parts of the slope, which indicates the importance of the geomorphological factor in formation of the soils. Usually, these soils contain fragments of calcareous rocks and have neutral reaction throughout the profile, but acidified topsoil layers may also appear, especially under a thick and acidic litter layer (Miechówka 2000). Humus-rich mountain rendzinas are typically covered with natural grassland communities (e.g. Seslerietalia variae) and may be still used for grazing (most often as the Arrhenatheretalia elatioris community). The humus-rich rendzina present in the lower zone of mountain forests provide the fertile habitats, proper for the beech forest community Dentario glandulosaeFagetum lunarietosum and the sycamore-featured forests Phyllitido-Aceretum. In the higher mountain zone, under the harsh climate that subsequently eliminates the less resistant broadleaf tree species, the humus-rich rendzinas are covered by "climatogenic" spruce forests, e.g. by the Polysticho-Piceetum tatricum community (Lasota et al. 2016).

The correlation of the humus-rich mountain rendzinas is somewhat ambiguous. Soils with strongly humus-enriched and deep mollic horizon undoubtedly belong to the chernozemic rendzinas, even if the origin of their mollic horizon is not identical to (presumed) genesis of the respective horizon in the upland chernozemic rendzinas. On the other hand, soils with thin A horizon (less than $20 \mathrm{~cm}$ ), even if these horizons have a black color and high humus content, belong in fact to the proper rendzinas (Miechówka and Drewnik 2018). A comparison of the forest habitats (based on Brożek and Zwydak 2001) leads to the conclusion that the thin humus-rich rendzinas and the proper rendzinas are covered with the same or very similar forest communities, so these soils have similar habitat value. The other problem of a correlation of the humus-rich mountain rendzinas is the acidic reaction found in some profiles. Mollic horizon cannot be identified in these cases and soils should be correlated with Umbrisols. Those soils do not have a proper analogue in the Polish Soil Classification at the moment (Systematyka gleb Polski 2011).

\section{BRIEF REVIEW OF THE INVESTIGATIONS FOCUSED ON RENDZINAS IN POLAND}

Despite the fact that rendzinas have a little contribution in the soil cover in Poland, they are popular research object, due to their unique physicochemical properties and the agricultural and forest significance 
different as compared to the soils developed from glacial deposits prevailing in Poland (Dobrzański 1976, Dobrzański et al. 1987). The investigations included all major areas of rendzina occurrence: the Lubelska Upland and Roztocze (Dobrzański 1955, Kuźnicki 1965), Kielce Upland including the Świętokrzyskie Mountains (Kuźnicki et al. 1976, Zagórski 2003) and Nida Basin (Ciarkowska 2000), KrakówCzęstochowa Upland (Uziak 1963b, Mazurek 2018), the Carpathian Mountains and their foothills (Dobrzański 1951, Uziak 1963a, 1969, Pomian 1964, Zasoński and Skiba 1988, Zasoński 1992), the Pieniny Mts. (Zagórski 1999a, 1999b, Niemyska-Łukaszuk et al. 2004, Zaleski et al. 2016, Kowalska et al. 2017), the Tatra Mts. (Adamczyk 1962a, 1962b, Komornicki 1977, Niemyska-Łukaszuk 1977a, 1977b, Skiba 1983, 1985, Komornicki and Skiba 1996, Miechówka 1989, 1998, 2000, 2002, Drewnik 2008, Lasota et al. 2016, Wasak and Drewnik 2012, 2015), the Silesian Upland including the Opole region (Licznar 1976), the Sudeten Mountains and their foreland (Kowaliński et al. 1972, Kowaliński and Licznar 1984), as well as the Pomerania and Lakeland in the north Poland (Uggla 1976, Lemkowska and Sowiński 2008, Lemkowska 2013, 2018).

The issue extensively studied by researchers is in particular the origin and occurrence of rendzinas in relation to the geological, geomorphological and climate factors (Dobrzański and Turski 1964, Kuźnicki 1965, Skiba 1983, 1985, Ciarkowska 2000, Zagórski 2003, Lemkowska and Sowiński 2008). In the investigations of the genesis of rendzinas and their parent materials, the micromorphological techniques are highly beneficial, thus commonly applied (Kowaliński and Licznar 1976, 1984, Licznar 1976, Zasoński and Skiba 1988, Zagórski 1999b, 2003, Ciarkowska and Niemyska-Łukaszuk 2004). Biological activity of rendzinas and the rate of transformation and accumulation of organic matter and the composition of the humic compounds formed in these soils were investigated mainly by the research groups in Krakow, and, in the past, also in Warsaw and Wrocław (Musierowicz and Skorupska 1966, Kuźnicki and Skłodowski 1968, 1976, Niemyska-Łukaszuk 1977a, 1977b, Kowaliński and Licznar 1986, Licznar et al. 1993, Niemyska-Łukaszuk and Miechówka 1996, Miechówka and Ciarkowska 1998, 2002, Ciarkowska and Miechówka 2005a, 2005b, Wasak 2013, 2014, Wasak and Drewnik 2012, 2015, 2018). Selected physicochemical properties, for example sorption properties and nutrient abundance in rendzinas, were investigated by, among others, Ciarkowska (2000), Miechówka (2002), Zagórski (2002), WójcikowskaKapusta and Niemczuk (2006), and Kowalska et al.
(2017), whereas the physical and water properties by Domżał et al. (1975), Turski et al. (1975), and Pranagal (2004). The mineralogy of the clay fraction, that has a significant influence on the physical and chemical properties of the rendzinas, was dealt, among others, with Zagórski (1999a) and Mocek et al. (2003). Geochemical studies on rendzinas, initiated to assess the current and potential richness in micronutrients and their availability for plants (Kabata-Pendias 1966, Sapek and Skłodowski 1976, Oleksynowa et al. 1977, Wójcikowska-Kapusta and Niemczuk 2009), currently have been continued mainly to approximate the degree of soil contamination with trace elements and to assess the environmental and health risks (Miechówka 1989, 1990, 2001, Brożek and Zwydak 2001, Mazurek et al. 2010, Smreczak et al. 2015).

\section{SUMMARY - THE RESEARCH CHALLENGES}

Despite numerous research papers related to rendzina soils in Poland, some issues still seem to be unsatisfactory resolved and deserve more attention in the future. Among many such issues, the following problems are worth to pay attention first.

1. The division into rendzinas and pararendzinas, introduced at the turn of the 1960s and 1970s, based on unclear and incomplete rules referring to the kind of parent rock, led to numerous inconsistencies in the naming and cartography of calcareous soils. Soils developed on limestone with the glacial silicate admixtures, for example in the Kielce and Lublin Uplands, are "mixed rendzinas", whereas the soils in the mountains, also on the limestones, but mixed with the material derived from non-calcareous rocks, for example in the Pieniny Mts, are called pararendzinas, similarly to soils developed from calcareous sandstones or shales, even if the latter contain more calcium carbonate than the "true" rendzinas (Kabała 2014). It seems that the additional result of this artificial division was the little attention paid to the soils that weren't the "real" rendzinas, existing in all areas, where the limestone/dolomite regolithes were significantly admixed with non-calcareous regolithes or glacial/periglacial materials. It seems that it will be more beneficial to resign of the division between rendzinas and pararendzinas at a high level of classification (in the Polish Soil Classification), to classify uniformly the soils developed of all rocks featured by the high content of calcium/magnesium carbonate (or gypsum). The rejection of this artificial division will remove the barriers hindering recognition of spatial relation- 
ships in the occurrence of the soils developed of mixed parent materials, for example from slope covers in the mountains or the colluvial covers in the uplands. In fact, this would be a return to general rules of uniform rendzina classification that existed until 1970s.

2. The issue of the so-called Quaternary or post-lake rendzinas, that are developed of the drained limnic calcareous sediments, such like a gyttja and lake chalk is still unresolved. These soils contain more than $40 \%$ of calcium carbonate directly below the humus horizon and often throughout the profile, which makes them similar to rendzinas in geochemical terms. Morphologically, these soils usually resemble the proper or chernozemic rendzinas, and the main difference is the lack of a rock fragments (skeleton) that are traditionally required as the reflection of the name "rędzina" meaning. However, it should be noted that in many thick chernozemic rendzinas developed of soft chalk limestone, the skeleton fraction also is negligible in the topsoil layers. Dry (drained) mineral post-limnic rendzinas and the "real" rendzinas create the habitats of similar value (in terms of the trophic status), which opens the way to their consolidation into one soil type (or types, respectively to the degree of profile development). When taking together the issues of "real" rendzinas, "post-limnic rendzinas" and "pararendzinas", a general conclusion should be highlighted on the need of the further improvement of the rules of classification of soils developed from carbonate rock and their mixed/transitional forms to non-calcareous soils (in the Polish Soil Classification).

3. Despite the numerous works on the transformation and forms of organic matter in the rendzina soils, the knowledge about the potential of carbon sequestration and organic carbon pools accumulated in rendzinas of Poland is relatively scarce, especially in uplands agricultural areas. Meanwhile, it seems that the high calcium content gives these soils a large potential for carbon sequestration, that should be adequately elaborated in the context of e.g. farming simplifications (e.g. minimum-till or no-till technologies) and afforestation of the post-arable lands.

4. Numerous papers on trace element concentration in rendzinas have allowed the general assessment of their enrichment and contamination with trace metals, but no reliable geochemical background for the arable topsoil of Polish rendzinas has been determined. Moreover, it has not been still answered, whether the rendzinas developed from limestones of the different age require separate reference tresholds (backgrounds) for the assessment of soil contamination with trace elements and other xenobiotics commonly used in agriculture or emitted by industry.

\section{ACKNOWLEDGEMENT}

I would like to thank all the members of the Soil Science Society of Poland, in particular the members of the Commission for the Soil Genesis, Classification and Cartography, who got involved in the implementation of the program "Soil of the Year", including the preparation of a special issue of Soil Science Annual focused on the rendzinas and related carbonate-rich soils.

\section{REFERENCES}

Adamczyk B., 1962a. Gleby tatrzańskie. [In:] Szafer W. (ed.) Tatrzański Park Narodowy. ZOP PAN Kraków: 149-166 (in Polish).

Adamczyk B., 1962b. Studia gleboznawczo-fitosocjologiczne w Dolinie Małej Łąki w Tatrach. Acta Agraria et Silvestria, 2: 45-116 (in Polish with English abstract).

Ad-Hoc-Arbeitsgruppe Boden der Staatlichen Geologischen Dienste und der Bundesanstalt für Geowissenschaften und Rohstoffe, 2005. Bodenkundliche Kartieranleitung (KA 5). Schweizerbart: $333 \mathrm{pp}$.

Altermann M., Rinklebe J., Merbach I., Körschens M., Langer U., Hofmann B., 2005. Chernozem - soil of the year 2005. Journal of Plant Nutrition and Soil Science 168(6): 725-740.

Badía D., Martí C., Aguirre A.J., Aznar J.M., González-Pérez J.A., De la Rosa J.M., Echeverría T., 2014. Wildfire effects on nutrients and organic carbon of a Rendzic Phaeozem in NE Spain: changes at cm-scale topsoil. Catena 113: 267-275.

Bodziarczyk J., 2004. Jaworzyny Pienińskiego Parku Narodowego. Studia Naturae 49: 61-86. (in Polish with English abstract).

Brożek S., Zwydak M., 2001. Zawartość żelaza ogółem w wybranych skałach macierzystych gleb leśnych Polski. Roczniki Gleboznawcze - Soil Science Annual 52(supplement): 167175 (in Polish with English abstract).

Brożek S., Zwydak M., 2003. Atlas gleb leśnych Polski. CILP. Warszawa: 127 pp. (in Polish).

Ciarkowska K., 2000. Charakterystyka gipsowych rędzin brunatnych. Roczniki Gleboznawcze - Soil Science Annual 51 (1-2): 101-111 (in Polish with English abstract).

Ciarkowska K., 2001. Sorption properties of gypsic rendzinas from the Niecka Nidzianska area. Acta Agrophysica 50: 71-79.

Ciarkowska K., Miechówka A., 2005a. Aktywność biologiczna górskich rędzin próchnicznych wytworzonych ze skał węglanowych i gipsowych Dolomitów. Część I. Mikromorfometryczne wskaźniki aktywności fauny glebowej i aktywność dehydrogenaz. Problemy Zagospodarowania Ziem Górskich 52: 57-64 (in Polish with English abstract).

Ciarkowska K., Miechówka A., 2005b. Aktywność biologiczna górskich rędzin próchnicznych wytworzonych ze skał węglanowych i gipsowych Dolomitów. Część II. Wpływ aktywności fauny glebowej na skład frakcyjny połączeń próchnicznych. Problemy Zagospodarowania Ziem Górskich 52: 65-70 (in Polish with English abstract). 
Ciarkowska K., Miechówka A., 2018. Gypsic rendzinas of Nida Basin (southern Poland): a review. Soil Science Annual 69(2): 101-108 (this issue).

Ciarkowska K., Niemyska-Łukaszuk J., 2004. Budowa mikromorfologiczna i wybrane wlasciwosci gipsowych redzin czarnoziemnych terenu Niecki Nidzianskiej i kotliny Vallada Agordina [Dolomity Włoskie]. Roczniki Gleboznawcze - Soil Science Annual 55(4): 15-22 (in Polish with English abstract).

Dobrzański B., 1951. Występowanie rędzin na skałach fliszu karpackiego. Annales UMCS, E, 5: 255-275 (in Polish with English abstract).

Dobrzański B., 1955. Rędziny Lubelszczyzny. Roczniki Gleboznawcze - Soil Science Annual 4: 192-201 (in Polish with English abstract).

Dobrzański B., 1976. Przydatność rolnicza rędzin. Roczniki Gleboznawcze - Soil Science Annual 27(2): 83-89 (in Polish with English abstract).

Dobrzański B., Konecka-Betley K., Kuźnicki F., Turski R., 1987. Rędziny Polski. Roczniki Nauk Rolniczych D 208: 143 pp. (in Polish with English abstract).

Dobrzański B., Szember A., Zawadzki S., 1953. Fizyczno-chemiczna i biologiczna charakterystyka niektórych gleb Kotliny Kłodzkiej. Annales UMCS, Sectio E 8: 283-306 (in Polish with English abstract).

Dobrzański B., Turski R., 1964. Próba określenia genezy rędzin na podstawie występowania minerałów ciężkich. Roczniki Gleboznawcze - Soil Science Annual 14 (dodatek): 295-301 (in Polish with English abstract).

Domżał H., Martyn W., Słowińska-Jurkiewicz A., 1975. Wykorzystanie oznaczeń wodno-powietrznych właściwości rędzin do określania wilgotności początku nawadniania oraz wielkości dawek polewowych. Roczniki Gleboznawcze - Soil Science Annual 26(3): 183-191 (in Polish with English abstract).

Drewnik M., 2008. Geomorfologiczne uwarunkowania rozwoju pokrywy glebowej w obszarach górskich na przykładzie Tatr. Wydawnictwo UJ, Kraków: 118 pp. (in Polish with English abstract).

Genetyczna klasyfikacja gleb Polski, wydanie 2, 1959. Roczniki Gleboznawcze - Soil Science Annual 7(2): 103 pp. (in Polish with English abstract).

Harbar V., Poznyak S., 2016. Genesis and properties of rendzinas in the Podilski Tovtry. Polish Journal of Soil Science, 48(2): 229-236.

IUSS Working Group WRB, 2015. World References Base for Soil Resources 2014, Update 2015, World Soil Resources Reports, 106, FAO, Rome: 186 pp.

Kabała C., 2014. Systematyka Gleb Polski - stan aktualny i dalszy rozwój. Soil Science Annual 65(2): 91-98 (in Polish with English abstract).

Kabała C., 2017. Gleba Roku PTG. Czarna Ziemia 23, http://ptg-wroclaw.up.wroc.pl/Czarna_Ziemia.html

Kabała C., Świtoniak M., Charzyński P., 2016. Correlation between the Polish Soil Classification (2011) and international soil classification system World Reference Base for Soil Resources (2015). Soil Science Annual 67(2): 88-100.

Kabata-Pendias A., 1966. Badania geochemiczno-mineralogiczne dwóch rędzin woj. kieleckiego. Roczniki Nauk Rolniczych A, 92: 349-374 (in Polish with English abstract).

Kacprzak A., Drewnik M., Uzarowicz Ł., 2006. Rozwój i kierunki przemian węglanowych gleb rumoszowych na terenie
Pienińskiego Parku Narodowego. Pieniny Przyroda i Człowiek 9: 41-50 (in Polish with English abstract).

Klasyfikacja gleb leśnych Polski, 2000. CILP, Warszawa: 127 pp. (in Polish with English abstract).

Komornicki T., 1977. Tatrzańskie rędziny strefy leśnej. Roczniki Gleboznawcze - Soil Science Annual 28(1): 277-291 (in Polish with English abstract).

Komornicki T., Skiba S., 1996. Gleby. [W:] Przyroda Tatrzańskiego Parku Narodowego. [W:] Mirek Z. (red.). Tatrzański Park Narodowy, Kraków-Zakopane: 215-226 (in Polish with English abstract).

Kowaliński S., Licznar M., 1976. Właściwości mikromorfologiczne niektórych rędzin wytworzonych $\mathrm{z}$ wapieni różnych formacji geologicznych. Roczniki Gleboznawcze-Soil Science Annual 37: 2-3 (in Polish with English abstract).

Kowaliński S., Licznar S.E., 1984. Właściwości mikromorfologiczne i fizykochemiczne rędzin występujących na terenie Rowu Nysy Kłodzkiej. Roczniki Gleboznawcze - Soil Science Annual 35(1): 125-139 (in Polish with English abstract).

Kowaliński S., Licznar S.E., 1986. Związki próchniczne w rędzinach wytworzonych z wapieni różnych formacji geologicznych. Roczniki Gleboznawcze - Soil Science Annual 37(2-3): 159-167 (in Polish with English abstract).

Kowaliński S., Licznar S., Drozd J., Licznar M., 1972. Pokrywa glebowa rezerwatu Muszkowicki Las Bukowy (Soils in the reserve Muszkowicki Las Bukowy). Ochrona Przyrody 37: 67-87 (in Polish with English abstract).

Kowalska J., Kajdas B., Zaleski T., 2017. Variability of morphological, physical and chemical properties of soils derived from carbonate-rich parent material in the Pieniny Mountains (south Poland). Soil Science Annual 68(1): 27-38.

Kölli R., Tamm I., 2015. Soil on limestone-year 2015 soil of Estonia. Agraarteadus 26, 2: 51-61.

Kuźnicki F., 1965. Właściwości i typologia gleb wytworzonych z kredowej opoki odwapnionej Roztocza w nawiązaniu do charakterystyki i genetycznego podziału rędzin. Roczniki Gleboznawcze - Soil Science Annual 15(2): 345-408 (in Polish with English abstract).

Kuźnicki F., Białousz S., Kamińska H., Oszmiańska M., Skłodowski P., Ziemińska A., Żakowska H., 1976. Rędziny wytworzone ze skał węglanowych różnych formacji geologicznych na obszarze Gór Świętokrzyskich i ich obrzeżenia. Roczniki Gleboznawcze - Soil Science Annual 27(2): 19-48 (in Polish with English abstract).

Kuźnicki F., Skłodowski P., 1968. Przemiany substancji organicznej w niektórych typach gleb Polski. Roczniki Gleboznawcze - Soil Science Annual 19(1): 3-25 (in Polish with English abstract).

Kuźnicki F., Skłodowski P., 1976. Zawartość i charakterystyka form związków próchnicznych w rędzinach wytworzonych ze skał węglanowych różnych formacji geologicznych. Roczniki Gleboznawcze - Soil Science Annual (27)2: 127-136 (in Polish with English abstract).

Lasota J., Błońska B., Pacanowski P., 2018. Forest sites and forest types on redzinas in Poland. Soil Science Annual 69(2): 121-129 (this issue).

Lasota J., Błońska E., Zwydak Z., 2016. Warunki glebowe świerczyny nawapiennej (Polysticho-Piceetum) w górnej części regla dolnego Tatr. Sylwan 160(5): 407-415 (in Polish with English abstract). 
Lemkowska B., 2013. „Rędziny czwartorzędowe” w Systematyce gleb Polski. Soil Science Annual 64(4): 135-139 (in Polish with English abstract).

Lemkowska B., 2018. Limnic Rendzinas in the Mazurian Lakeland (NE Poland). Soil Science Annual 69(2): 109-120 (this issue).

Lemkowska B., Sowiński P., 2008. Ewolucja „rędzin pojeziornych" w krajobrazie Pojezierza Mazurskiego. Roczniki Gleboznawcze - Soil Science Annual 59(1): 134-140 (in Polish with English abstract).

Licznar S.E., 1976. Rędziny i gleby nawapieniowe Opolszczyzny w świetle badań mikromorfologicznych i fizykochemicznych. Roczniki Gleboznawcze - Soil Science Annual 27(3): 73-121 (in Polish with English abstract).

Licznar S.E., Drozd J., Licznar M., 1993. Skład frakcyjny próchnicy rędzin Polski południowo-zachodniej. Zeszyty Problemowe Postępów Nauk Rolniczych 411: 131-138 (in Polish with English abstract).

Mazurek R., Kowalska J.B., Zadrożny P., Gąsiorek M., Kozak H., 2018. Rendzinas diversity of the Ojców National Park as an effect of lithological factors. Soil Science Annual 69(2): $130-141$ (this issue)

Mazurek R., Wieczorek J., Zadrożny P., 2010. Mercury Content in Soils of The Ojców National Park. Ecological Chemistry and Engineering A, 17(4-5): 439-447.

Miechówka A., 1989. Charakterystyka geochemiczna rędzin tatrzańskich wytworzonych z dolomitów. Cz. I. Ogólna charakterystyka gleb i niektóre dane mineralogiczne. Roczniki Gleboznawcze - Soil Science Annual 40(2): 83-105 (in Polish with English abstract).

Miechówka A., 1990. Charakterystyka geochemiczna rędzin tatrzańskich wytworzonych z dolomitów. Cz. II. Właściwości chemiczne badanych gleb. Roczniki Gleboznawcze - Soil Science Annual 41(3/4): 29-48 (in Polish with English abstract).

Miechówka A., 1998. Charakterystyka rędzin występujących powyżej górnej granicy lasu w Tatrach. Studia Ośrodka Dokumentacji Fizjograficznej PAN 25: 41-60 (in Polish with English abstract).

Miechówka A., 2000. Charakterystyka tatrzańskich gleb nieleśnych wytworzonych ze skał węglanowych. Zeszyty Naukowe AR w Krakowie, Rozprawy 263: 86 pp. (in Polish with English abstract).

Miechówka A., 2001. Zawartość różnych form żelaza w rędzinach położonych powyżej górnej granicy lasu w Tatrach. Roczniki Gleboznawcze - Soil Science Annual 52(supl.): 135-143. (in Polish with English abstract).

Miechówka A., 2002. Wybrane właściwości rędzin występujących pod kosodrzewiną w Tatrzańskim Parku Narodowym. Roczniki Gleboznawcze - Soil Science Annual 53(1-2): 1-8 (in Polish with English abstract).

Miechówka A., Ciarkowska K., 1998. Mikromorfologiczne formy próchnicy tatrzańskich rędzin próchnicznych i butwinowych. Zeszyty Problemowe Postępów Nauk Rolniczych 464: 161168 (in Polish with English abstract).

Miechówka A., Ciarkowska K., 2002. Aktywność fauny glebowej w rędzinach organicznych i próchnicznych obszarów nieleśnych Tatrzańskiego Parku Narodowego. Przemiany środowiska przyrodniczego Tatr. Kraków-Zakopane 2002: 111-115 (in Polish with English abstract).
Miechówka A., Drewnik M., 2018. Rendzina soils in the Tatra Mountains, central Europe: a review. Soil Science Annual 69(2): 88-100 (this issue).

Mieczyński T., 1932. Zarys fizyczno-geograficzny województwa lubelskiego. [In:] Czuma I. Monografia statystyczno-gospodarcza województwa lubelskiego. Lublin: 1-89 (in Polish).

Miklaszewski S., 1922. Contribution à la connaissance des sols nommés „Rendzina”. V Comptes Rendus de la Conférence extraordinaire (III-e internationale) Agropédologique à Prague. Publié par Stâtni vyzkumny ustav agropedologicky (Institut agropédologique de l'Etat) à Prague. Tchécoslovaquie: 245-251.

Miklaszewski S., 1930. Gleby Polski. Komisja Wydawnicza TBPS Politechniki Warszawskiej, Warszawa: 640 ss. (in Polish).

Mocek A. (red.), 2015. Gleboznawstwo. Wydawnictwo Naukowe PWN SA, Warszawa: 571 pp. (in Polish).

Mocek A., Spychalski W., Kaczmarek Z., 2003. Właściwości fizyczne oraz skład mineralogiczny frakcji koloidalnej rędzin różnych formacji geologicznych. Roczniki Gleboznawcze 2: 111-119 (in Polish with English abstract).

Musierowicz A., 1954. Klasyfikacja gleb Polski ustalona przez Polskie Towarzystwo Gleboznawcze. Roczniki Gleboznawcze - Soil Science Annual 3: 3-24 (in Polish with English abstract).

Musierowicz A., Skorupska T., 1966. Frakcje związków humusowych czarnoziemu, czarnych ziem i rędzin. Roczniki Nauk Rolniczych A, 91(2): 1-50 (in Polish with English abstract).

Musierowicz A., Wondrausch A., 1936. Rędziny północnej krawędzi Podola. Pierwsza Związkowa Drukarnia we Lwowie: 86 pp. (in Polish with English abstract).

Niemyska-Łukaszuk J., 1977a. Charakterystyka próchnicy niektórych leśnych gleb tatrzańskich. Cz. II. Skład frakcyjny połączeń próchnicznych, Roczniki Gleboznawcze-Soil Science Annual 28(1): 170-188 (in Polish with English abstract).

Niemyska-Łukaszuk J., 1977b. Charakterystyka próchnicy niektórych leśnych gleb tatrzańskich. Cz. III. Mikromorfologia poziomów butwinowych. Roczniki Gleboznawcze - Soil Science Annual 28(1): 189-203 (in Polish with English abstract).

Niemyska-Łukaszuk J., Miechówka A., 1996. Charakterystyka połączeń próchnicznych rędzin tatrzańskich. [W:] Kotarba A. (ed.) Przyroda Tatrzańskiego Parku Narodowego a człowiek. Tom 1. Nauki o Ziemi. TPN - PTNoZ, Kraków-Zakopane: 179-275 (in Polish with English abstract).

Niemyska-Lukaszuk J., Zaleski T., Miechówka A., 2004. Charakterystyka pokrywy glebowej Pienińskiego Parku Narodowego. Studia Naturae 49: 33-41 (in Polish with English abstract).

Oleksynowa K., Skiba S., Kania W., 1977. Wstępne badania nad geochemią rędzin tatrzańskich. Roczniki Gleboznawcze - Soil Science Annual 28(1): 263-275 (in Polish with English abstract).

Polskie Towarzystwo Gleboznawcze, 2017. Przewodnik terenowy do opisu gleb. Warszawa, 49 ss. http://ptg.sggw.pl/wp-con tent/uploads/2018/04/Przewodnik_do_opisu_gleby_PTG_01min.pdf

Pomian J., 1964. Warunki występowania rędzin w terenie Karpat fliszowych. Roczniki Gleboznawcze - Soil Science Annual 1 (suppl.): 249-258 (in Polish with English abstract).

Pranagal J., 2004. Porowatość różnicowa rędziny i wodoodporność jej agregatów w różnych systemach uprawy. Roczniki Gleboznawcze - Soil Science Annual 55(2): 339-347 (in Polish with English abstract). 
Radmanović S.B., Đorđević A.R., Nikolić N.S., 2015. Humification degree of Rendzina soil humic acids influenced by carbonate leaching and land use. Journal of Agricultural Sciences 60(4): 443-453.

Sapek A., Skłodowski P., 1976. Zawartość Mn, Zn, Cu, Pb, Ni i Co w rędzinach Polski. Roczniki Gleboznawcze - Soil Science Annual 27(2): 137-144 (in Polish with English abstract).

Skiba S., 1983. Tendencje do strefowości rędzin tatrzańskich na przykładzie stoków Kominiarskiego Wierchu. Roczniki Gleboznawcze - Soil Science Annual 34(4): 101-112 (in Polish with English abstract).

Skiba S., 1985. Rola klimatu i roślinności w genezie gleb na przykładzie gleb górskich z Tatr Polskich i z gór Mongolii. Zeszyty Naukowe AR w Krakowie, Rozprawy Habilitacyjne 99: 72 ss. (in Polish with English abstract).

Skiba S., Komornicki T., 1983. Gleby organiczno-sufozyjne w Tatrach Polskich. Roczniki Gleboznawcze - Soil Science Annual 34(4): 113-122 (in Polish with English abstract).

Skłodowski P., 2014. Sylwetki polskich gleboznawców: Sławomir Miklaszewski. Czarna Ziemia 10 http://ptg-wroclaw.up.wroc.pl/CzarnaZiemia_10.htm

Smreczak B., Jadczyszyn J., Kabała C., 2018. Przydatność rolnicza rędzin w Polsce. Soil Science Annual 69(2): 142-151 (this issue).

Smreczak B., Jadczyszyn J., Klimkowicz-Pawlas A., UkalskaJaruga A., 2015. Stan zanieczyszczenia gleb pierwiastkami śladowymi oraz struktura użytkowania gruntów w rejonie Olkusza. Studia i Raporty IUNG-PIB 46(20): 125-141 (in Polish with English abstract).

Soil Survey Staff, 2014. Keys to Soil Taxonomy, 12th ed. USDA, Natural Resources Conservation Service, Washington, DC: 356 pp.

Stremme H., 1932. Die Bodenkartierung. [In:] Blanck E. (Ed.) Handbuch der Bodenlehre. Springer, Berlin, Heidelberg: 259-428.

Strzemski M., 1950. Rędziny na wapieniach triasowych w okolicach Piekoszowa. Roczniki Gleboznawcze - Soil Science Annual 1: 99-103 (in Polish with English abstract).

Strzemski M., Siuta J., Witek T., Bury-Zaleska J., Nowosielski O., Słowik K., Trębski L., Truszkowska R., 1973. Przydatność rolnicza gleb Polski. PWRiL: 285 pp. (in Polish with English abstract).

Systematyka gleb Polski (Polish Soil Classification), 1974. Roczniki Gleboznawcze - Soil Science Annual 25(1): 1-148 (in Polish with English abstract).

Systematyka gleb Polski (Polish Soil Classification), 1989. Roczniki Gleboznawcze - Soil Science Annual 40(3/4): 1-150 (in Polish with English abstract).

Systematyka gleb Polski (Polish Soil Classification), 2011. Roczniki Gleboznawcze - Soil Science Annual 62(3): 1-193 (in Polish with English abstract).

Świtoniak M., Kabała C., Charzyński P., 2016. Proposal of English equivalents for the soil taxa names in the Polish Soils Classification. Soil Science Annual 67(3): 103-116.

Turski R., Domżał H., Słowińska-JurkiewiczA., Martyn W., 1975. Wpływ frakcji ilu koloidalnego, węglanu wapnia i próchnicy na zawartość wody silnie związanej, plastyczność i pęcznienie rędzin. Roczniki Gleboznawcze - Soil Science Annual 26(3): 35-43 (in Polish with English abstract).

Uggla H., 1976. „Rędziny” Pojezierza Mazurskiego. Roczniki Gleboznawcze - Soil Science Annual 27(2): 113-125 (in Polish with English abstract).
Uziak S., 1963a. Geneza i klasyfikacja gleb górskich w Karpatach fliszowych. Roczniki Gleboznawcze - Soil Science Annual 13: 56-70 (in Polish with English abstract).

Uziak S., 1963b. Rzekome rędziny jurajskie Wyżyny Krakowsko-Częstochowskiej. Annales UMCS, B, 8: 23-30 (in Polish with English abstract).

Uziak S., 1969. Wpływ rzeźby terenu na typologiczne zróżnicowanie pokrywy glebowej w Karpatach Fliszowych. Roczniki Gleboznawcze - Soil Science Annual 20(1): 81-97 (in Polish with English abstract).

Wasak K., 2013. Zastosowanie wybranych systemów klasyfikacji do określenia typów materii organicznej w glebach leśnych w Tatrach. Prace Geograficzne 135: 101-119 (in Polish with English abstract).

Wasak K., 2014. Cellulose decomposition rate and features of organic matter in forest soils in the Tatra Mountains. Hruntoznavstvo 15: 70-80.

Wasak K., Drewnik M., 2012. Properties of humus horizons of soils developed in the lower montane belt in the Tatra Mountains. Polish Journal of Soil Science 45(1): 57-68.

Wasak K., Drewnik M., 2015. Land use effects on soil organic carbon sequestration in calcareous Leptosols in former pastureland - a case study from the Tatra Mountains (Poland). Solid Earth 6: 1103-1115.

Wasak K., Drewnik M., 2018. Sequestration of organic carbon in rendzinas: a review. Soil Science Annual 69(2): 75-87 (this issue).

Wójcikowska-Kapusta A., Niemczuk B., 2006. Wpływ sposobu użytkowania na zawartość różnych form magnezu i potasu w profilach rędzin. Acta Agrophysica 8(3): 765-771 (in Polish with English abstract).

Wójcikowska-Kapusta A., Niemczuk B., 2009. Copper speciation in different-type soil profiles. Journal of Elementology 14(4): $815-824$.

Zagórski Z., 1999a. Clay minerals of brown rendzina soils from the Male Pieniny Mts. Annals of Warsaw Agricultural University, Agriculture 35: 21-29.

Zagórski Z., 1999b. Cechy mikromorfologiczne i niektóre właściwości gleb wapniowcowych z terenu Małych Pienin. Roczniki Gleboznawcze - Soil Science Annual 50(1/2): 115-126 (in Polish with English abstract).

Zagórski Z., 2002: The influence of the mineral composition of the clay fraction on zinc sorption in rendzina soils. Polish Journal of Soil Science 35(1): 39-45.

Zagórski Z., 2003. Mineralogiczne i mikromorfologiczne wskaźniki genezy i właściwości rędzin wytworzonych ze skał węglanowych różnych formacji geologicznych. Fundacja „Rozwój SGGW” (in Polish with English abstract).

Zagórski Z., Kaczorek D., 2002. Haematite - a lithogenetic form of iron in soils from the southern part of the Holy Cross Mts. Annales of Warsaw Agricultural University-SGGW, Agriculture 43: 17-23.

Zaleski T., Mazurek R., Gąsiorek M., Wanic T., Zadrożny P., Józefowska A., Kajdas B., 2016. Gleby leśnych powierzchni monitoringowych w Pienińskim Parku Narodowym. Pieniny Przyroda i Człowiek 14: 3-15 (in Polish with English abstract).

Zasoński S., 1992. Warstwy krośnieńskie jako skała macierzysta pararędzin fliszowych (na przykładzie gleb Wzgórz Rymanowskich). Roczniki Gleboznawcze - Soil Science Annual 43(3/4): 77-90. 
Zasoński S., Skiba S., 1988. Chemiczne i mikromorfologiczne właściwości gleb wapniowcowych okolic Cieszyna. Roczniki Gleboznawcze - Soil Science Annual 39(3): 71-90 (in Polish with English abstract).

Zwydak M., 2011. Morfologia oraz podstawowe właściwości chemiczne gleb zespołu jaworzyny z języcznikiem zwyczajnym (Phyllitido-Aceretum Moor 1952) w Polsce. Roczniki
Gleboznawcze - Soil Science Annual 62(1): 177-186 (in Polish with English abstract).

Received: May 14, 2018

Accepted: July 9, 2018

Associated editor: t. Uzarowicz

\section{Rędzina - Gleba Roku 2018 w Polsce. Wprowadzenie do genezy, klasyfikacji i użytkowania rędzin}

Streszczenie: Podobnie jak towarzystwa gleboznawcze w innych krajach, Polskie Towarzystwo Gleboznawcze rozpoczęło realizacje programu „Gleba Roku”, a na glebę inaugurującą program w 2018 roku została wytypowana rędzina. Polskie określenie „rędzina” zostało w międzynarodowym gleboznawstwie spopularyzowane przez S. Miklaszewskiego w latach 20. XX wieku i do dziś występuje w klasyfikacjach jako „Rendzina”, „Rendoll” lub „Rendzic”. W polskiej tradycji, rędzinami nazywane są gleby wietrzeniowe wytworzone ze skał masywnych bogatych w kalcyt, dolomit lub gips, dość często z domieszkami materiałów glacjalnych/peryglacjalnych lub stokowych, we wszystkich stadiach rozwojowych. Współczesne polskie klasyfikacje wyróżniają cztery główne grupy (w randze typu lub podtypów) rędzin: inicjalne - Calcaric Lithic/Hyperskeletic Leptosols (minimalna grubość zwietrzeliny i inicjalne ukształtowanie poziomów genetycznych), właściwe - Calcaric Leptosols (dobrze ukształtowany profil, ale brak poziomów diagnostycznych), brunatne - Calcaric Skeletic Cambisols (obecny poziom cambic) i czarnoziemne - Rendzic Skeletic Phaeozems (obecny poziom mollic). Rędziny wyróżnia zasobność w wapń/magnez, obojętny lub zasadowy odczyn i wysokie wysycenie zasadami w całym profilu, ale poszczególne podtypy rędzin znacznie różnią się wartością siedliskową i użytkową, w zależności od miąższości profilu (głębokości do litej skały lub silnie szkieletowego podłoża), szkieletowości, uziarnienia i zawartości próchnicy.

Stowa kluczowe: rędziny, geneza gleb, systematyka gleb, funkcje gleb 